\title{
Military Loyalty and the Failure of Democratization in Africa: How Ethnic Armies Shape the Capacity of Presidents to Defy Term Limits
}

\author{
Kristen A. Harkness \\ School of International Relations \\ University of St. Andrews ${ }^{1}$ \\ Open Access Copy-Please Do Not Cite \\ Forthcoming in Democratization
}

\begin{abstract}
The military plays a crucial role in furthering or hindering democratization in Africa. Beyond direct intervention through coups, armies more subtly and perniciously condition the political trajectory of states through their loyalty. Leaders who can rely on unwavering military support for protection against internal unrest face fewer risks and greater chances of success in rolling back liberalization and entrenching authoritarian practices. Constructing ethnic armies, which tie the fate of soldiers to the regime, is a profoundly powerful way to affect such loyalty. Through a mixed methods analysis of presidential bids to challenge term limits, including a paired comparison of Senegal and Cameroon, I demonstrate that ethnic armies triple the chances of success and, in so doing, encourage defiance in the first place: $82 \%$ of presidents back by ethnic armies attempt to defy their constitutions and extend their hold on power, as opposed to $31 \%$ of other leaders. Conversely, ethnically diverse armies are far more likely to defend constitutional politics and constrain leaders to abide by term limits. The ethnic composition of the military thus critically shapes the prospects for African liberalization.
\end{abstract}

Key Words: democratization, term limits, civil-military relations, ethnic politics, African politics

Many African countries took their "indispensable first steps" toward liberalization ${ }^{2}$ and free and fair elections after the end of the Cold War. ${ }^{3}$ Long-time dictators were voted out of office, multi-party competition replaced single party regimes, and respect for civil liberties and human rights increased. Yet, consolidation of these initial gains has proved elusive. Despite the passage of over two decades since its democratic opening, Freedom House rates only $12 \%$ of Africa free today. ${ }^{4}$ Prolonged and subtle shifts back to authoritarian practices and sharp reversals at the hands of antidemocratic forces have eroded hard won political and civil liberties. The 
question of how African democracy can be deepened, and authoritarian regression prevented, remains vital.

This article will argue that the military plays a crucial and under-studied role in promoting or hindering liberalization in Africa. Soldiers can and do seize power, directly undermining constitutional politics and threatening a return to military governance. But militaries also play a much more subtle and perhaps pernicious role in undermining democratization. Leaders rely on their militaries for protection against both internal and external threats. Where military loyalty is ensured through personal or ethnic bonds, presidents can discount domestic challenges to their rule, untying their hands to pursue authoritarian practices. Through an analysis of presidential bids to defy term limits, I show that leaders who can count on the aid of a coethnic army are both more likely to challenge term limits and more successful in so doing. More optimistically, ethnically diverse armies seem far more likely to defend constitutional politics and constrain leaders to abide by term limits. With only two exceptions, leaders who challenged their term limits without benefiting from an ethnically loyal army, failed in those bids. The ethnic composition of the military thus critically shapes the prospects for African liberalization.

This argument contributes to a small but growing literature on the role of the military in democratization processes. Extant work has focused predominantly on direct military intervention, in the form of coups d'état. ${ }^{5}$ Collier, for example, has opined that military coups are the only realistic way to remove highly repressive and long ruling dictators. ${ }^{6}$ Taking up this argument, Thyne and Powell find that coups promote democratization in contexts where it is least likely to occur otherwise, in highly authoritarian states with long-standing rulers. ${ }^{7}$ 
Additionally, Miller argues that irregular transfers of power, mostly constituted by coups, lead to democratization when unseating economically developed autocracies, while Marinov and Goemans find that coups lead to democratization conditional on high levels of western aid. ${ }^{8}$ Gürsoy argues that even failed coup plots can facilitate democratization where their aftermaths encourage soldiers to accept civilian rule. ${ }^{9}$

Others, however, have argued that coups undermine democracy. Tusalem analyzes countries transitioning to democracy and finds that the higher the degree of military politicization and past coup interventionism, the more deleterious the effect on democratic consolidation. ${ }^{10}$ Harkness argues that democratization threatens previously ethnically stacked militaries, who now face a severe threat to their privileged position within the state and access to an important source of patronage. To protect their benefits, such ethnic armies intervene and block democratization or reverse the outcomes of elections. ${ }^{11}$

While acknowledging that coups matter, this article transcends this prior focus, demonstrating that militaries need not seize the reigns of government themselves to powerfully impact the democratization of the state. Their loyalty matters, whether to a coethnic president or to the constitution, and can make the difference between further liberalization and the return of authoritarianism.

\section{Challenging Term Limits}

Nullifying term limits has emerged as one of the primary means through which African presidents consolidate their power and shift back towards authoritarianism. ${ }^{12}$ Term limits are considered by many to provide a vital check on executive power and enable deepening 
democratization. They increase the transparency and fairness of elections, facilitate alternations in governing political parties, build trust in democratic institutions, and create a focal point around which citizens, opposition parties, and NGOs can mobilize to defend constitutionalism. ${ }^{13}$ By legally nullifying or otherwise ignoring term limits, African presidents not only sacrifice these democratic gains but also undermine the key mechanism for their removal, extending their tenure indefinitely and allowing further abuses of power. Moreover, they do so through quasiacceptable legal maneuvering, allowing pseudo-democratic but presidentially controlled legislatures, judiciaries, and popular referenda do their dirty work for them, rather than resorting to more overt and costly forms of violence that would trigger international condemnation and the suspension of aid flows. Recent culprits span the continent, encompassing leaders from 18 different countries (see Table 1).

[Table 1 about here $\left.{ }^{14}\right]$

Yet, not all presidents choose to challenge limits to their rule. Almost half accept their term limits gracefully. Moreover, not all bids to ignore term limits or amend constitutions to nullify them succeed: nearly $40 \%$ fail. Such variation raises important, interrelated empirical questions as to which factors shape the strategic decision to resist term limits and what then conditions success. In a preliminary effort to answer the first of these questions, Posner and Young find that presidential age, margin of victory in past elections, foreign aid dependence, oil wealth, and prior acceptance of term limits influence whether a leader challenges term limits..$^{15}$ What is so far missing from the analysis, as the following vignettes will show, is the potential role of the military in shaping these decisions and their outcomes. 
In April 2015, President Pierre Nkurunziza announced his intention to run for a third term in office, violating both the constitution and the Arusha peace accords that had ended Burundi's devastating civil war. Nkurunziza had already shown a tendency towards deepening autocratic practices such as censoring the media, engaging in electoral fraud, and threatening violence against NGOs and human rights activists. After his announcement, thousands of protestors filled the streets and were met with brutality. Police were authorized to fire indiscriminately into the crowds; the ruling party's youth militia were mobilized to beat and repress protestors; and neighborhoods thought to harbor dissenters were subjected to mass arrests and house-to-house searches. As the streets degenerated into violence, a faction of the military stepped in and attempted to seize power. Overpowered by loyal elements of the army, they failed. ${ }^{16}$

The coup attempt only succeeded in furthering Nkurunziza's resolve to cling to power. Fraudulent elections, marred by intimidation and violence, rubber stamped his continued rule. The regime cracked down on suspected opponents, inside and outside the military. Brutality against protestors intensified with escalating abuses by the police, intelligence services, and militias. Dead bodies became a common sight in the streets of the capital, with upwards of 400 estimated fatalities by the end of the year. Within the military, although the coup attempt was led by a coethnic Hutu General, Nkurunziza conflated Tutsi soldiers with the threat to his government: arresting, assassinating, and rotating them to remote posts. Officers and rank-andfile soldiers alike have defected to emerging rebel groups, which have begun conducting attacks. Having embraced authoritarianism, Burundi now teeters on the brink of renewed civil war. ${ }^{17}$

On the other side of the continent, in Burkina Faso, a similar attempt to defy term limits led to a very different outcome. Although President Blaise Compaoré rose to power through a 
military coup in 1987 , he had presided over the slow liberalization of the state and the adoption of a democratic constitution. In 2014, when he attempted to defy the term limits he had helped to create, bitter disagreements broke out with the opposition political parties and mass demonstrations turned nearly a million people onto the streets (in a country of only 17 million). As the regime turned increasingly to violence, Burkina Faso's military intervened and successfully took over the government. Within months, the constitution had been restored and a transitional civilian president elected by a special college of military, political, religious, and traditional leaders. Despite a failed counter-coup by Compaoré's elite presidential guard, democratic elections were held on November 29, 2015-marking the first time that elections had ever brought a new President to power in Burkina Faso. Compaoré's attempt to defy term limits thus counterintuitively resulted in a new opportunity for further liberalization and democratic consolidation. ${ }^{18}$

What both of these anecdotes suggest is that military loyalty may be critical to presidential survival when authoritarian tendencies encounter heavy resistance. Loyal units in Burundi's army ensured that Nkurunziza stayed in power and that his bid to defy term limits succeeded. Burkina Faso's constitutionally loyal military factions, on the other hand, prevailed over Compaoré's personally loyal presidential guard, resulting in his fall from power and a democratic reopening of the government. The following section develops a theoretical framework of how military loyalty—specifically ethnically-based loyalty—shapes whether presidential attempts to challenge term limits will succeed and, hence, whether leaders will strategically choose to risk such action in the first place. 


\section{Theoretical Framework: Military Loyalty and Presidential Bids to Defy Term Limits}

Reasserting authoritarianism runs the risk of provoking mass dissent. In the face of either violent challenges or civil resistance campaigns, leaders must rely on their security forces to protect their hold on power. Beyond stabilizing the regime against serious opposition, loyal soldiers also facilitate preemptive repression and thereby deter challenges, diminishing the likelihood that such opposition emerges in the first place. One prominent historic source of reliable military loyalty in Africa has been the construction of coethnic armies, which tie soldiers to the fate of their leader through ethnically exclusive recruitment and patronage practices. Unwavering military loyalty, created through shared ethnic ties, enables leaders to successfully rollback democratic gains, increasing the probability that they strategically seek to do so.

Challenging term limits is risky business. Afrobarometer data indicate that the majority of citizens in every single country surveyed support a limit of two terms for the presidency. ${ }^{19}$ Those who have pushed for the nullification of such limits have often faced intense opposition: from mass publics, from legislatures and courts, and even from their own political parties. ${ }^{20}$ As the vignettes of Burundi and Burkina Faso demonstrate, challenging term limits can lead not only to mass protests and street violence, but also to the rebellion of soldiers - fundamentally threatening the regime.

This potential for mass uprisings and widespread dissent makes the military a vital actor in the strategic calculus of leaders. Theoretical work on both authoritarian politics and civil resistance campaigns emphasizes the crucial role that militaries play in regime stabilization. As Svolik argues, autocratic governments face a critical "problem of authoritarian control." By their very nature, non-democratic systems exclude the majority of citizens from power and influence 
over policy. ${ }^{21}$ To stabilize their exclusivity, dictators rely on repression, especially given limited resources for cooptation. ${ }^{22}$ While the military constitutes the agent of last resort for implementing this repression_- “everyday" repression being handled by the police, intelligence services, paramilitaries, and other specialized agents of internal security — it is nonetheless the only institution capable of defeating "mass, organized, and potentially violent opposition." 23 The loyalty of the security sector, and their willingness to stand by the regime and repress, are thus vital to maintaining authoritarian practices.

Similarly, research on non-violent civil resistance campaigns and revolutions have emphasized the crucial role of military loyalty in determining whether those movements succeed or fail. Chenoweth and Stephan argue that military defection, or loyalty shifts in their parlance, is a key causal mechanism explaining the success of civil resistance campaigns in achieving major objectives like regime change. They suggest that non-violent movements attract widespread participation, increasing the density of social links between protestors and security forces. This, in turn, increases the likelihood that ordinary soldiers will defy orders to fire into crowds, facilitating the fall of the regime. If the military remains steadfast in their support of the government, however, then the campaign is unlikely to succeed. ${ }^{24}$ Similarly, Barany argues that military loyalty was critical in determining the outcome of revolutionary movements during the Arab Spring. Where soldiers sided with the regime, it survived; where they defected and refused to fire on protestors, the government fell. ${ }^{25}$ Both of these strands of research thus highlight the importance of military loyalty, especially when mass mobilization arises.

Given the importance of military loyalty to autocratic stability, it should come as no surprise that leaders with authoritarian tendencies have developed many mechanisms for trying 
to guarantee that loyalty. Paramilitaries and presidential guards, personally loyal to the president and outside the normal chain of command, have been created. ${ }^{26}$ Expensive equipment, pay raises, and private enrichment opportunities have all been granted to "buy off" the military. ${ }^{27}$ And recruitment, promotion, and retention practices have been built around shared kinship or ethnicity. $^{28}$

While each of these mechanisms may enhance military loyalty in times of trouble, I focus on ethnic armies for two reasons. First, constructing military loyalty on ethnic foundations has been an historically widespread practice in Africa. Colonial African militaries were officered almost exclusively by white Europeans drawn from the metropole, while their rank-and-file soldiers were recruited from "martial races" deemed to be more politically reliable and fitted to military duties. ${ }^{29}$ Facing a precarious regional security environment, replete with threats of state failure, coups, and civil war, many independence era leaders looked to this model and built their armies on the basis of shared identity. Over half of Africa's postcolonial armies were stacked with the leaders' coethnics, creating an abiding legacy of ethnic armies across the continent. ${ }^{30}$

Second, shared ethnicity provides a particularly enduring and rigorous basis for military loyalty. Conditioning recruitment, retention, and promotion on shared identity within an important state institution reinforces the centrality of ethnicity within the political system and in the eyes of individuals. ${ }^{31}$ Soldiers thus become ever more likely to perceive that their privileges and benefits are tied directly to their identity and, moreover, to a coethnic regime retaining power. If another group took over, or even an ethnically diverse or neutral government, then their access to a prime source of patronage and security would be forfeited. The ethnic army's fate 
thus becomes bound with that of their leader. This makes them particularly predisposed to act in a unified manner and defend the current government at all costs.

We expect ethnic armies to remain loyal to their leaders and to support their bids to rollback liberalization and consolidate autocratic power, even in the face of mass dissent. Ethnic armies thus enable presidents to defy term limits and, by facilitating success, encourage the attempt.

\section{Research Design}

The remainder of this article employs a multi-method research design to test the argument that ethnic armies increase both the probability that leaders will attempt to nullify constitutional term limits and that they will be successful in so doing. First, cross-national descriptive statistics and bivariate logit models demonstrate general patterns. Due to the small universe of cases, regression analysis is inapplicable: as of 2016, only 37 African presidents had reached their constitutional two-term limit and, of these, 18 attempted to alter or ignore the constitution.

Based on these medium-N findings, a paired-comparison was then selected to analyze the contrasting role of the military in a successful case and a failed case of term limit challenges. Both President Wade in Senegal and President Biya in Cameroon attempted to defy the constitutional limits on their rule and extend their time in office. The institutional and historical contexts they faced were broadly similar: both Senegal and Cameroon were former French colonies; were governed for most of the post-independence period by authoritarian regimes that practiced widespread cooptation and patronage politics, thereby minimizing but not eliminating the need for more violent forms of repression; have experienced ethnically-based but relatively 
small-scale insurgencies; and possess economies dominated by exports, exposing them to commodity price fluctuations. Yet, while Wade failed and was voted out of office, Biya succeeded and continues to govern.

There are important contextual differences between the cases that should be acknowledged. While Senegal has very few mineral resources and an agriculturally-based export sector dominated by peanuts, Cameroon has been an oil producer since independence. Oil rents may constitute a political resource curse predisposing Cameroon to more authoritarian governance. ${ }^{32}$ Senegal also benefits from a longer history of quasi-democratic institutions. Under colonial rule, the four urban communes of Senegal were granted limited self-governance and political representation, both locally and within metropolitan France. Both of these factors could contribute to greater democratic prospects in Senegal. Both are, however, background conditions and I will argue that the more proximal factor of military loyalty played a direct role in conditioning the outcome of each president's challenge to term limits.

\section{Cross-National Analysis}

Cross-national data on all African presidents that reached their two term limit, whether they challenged those limits, and whether they succeeded was obtained from Posner and Young. ${ }^{33}$ Only two new cases were added: Boni Yayi's recent failed attempt (2016) to alter Benin's constitution to allow a third term and Wade's failed electoral campaign in Senegal (2012) after successfully pressuring the courts to permit his unconstitutional reelection bid. Table 1 presents the complete universe of cases, broken down by outcome. 
I coded original data on whether the leader benefitted from the backing of a coethnic army from a wide range of primary and secondary sources. Leaders have historically employed two methods for building ethnic armies: stacking the officer corps of the army with coethnics or creating elite coethnic paramilitary units (i.e. Presidential Guards), that operate outside the normal command structure of the military and are often better trained and equipped than the regular army. ${ }^{34}$ Thus, if the president reaching their term limits had previously disproportionately recruited coethnics into the officer corps of the military, or into an elite presidential guard, then Ethnic Army is coded as 1, and 0 otherwise. ${ }^{35}$ The online appendix contains a summary of the coding decisions, a brief narrative of the collected evidence for each case, and full source citations.

Leaders who benefitted from the backing of an ethnically loyal military were significantly more likely to challenge their term limits. Presidents who had constructed coethnic security institutions account for over half the total number of such challenges and the bivariate relationship is statistically significant (see Table 2 ). While $31 \%$ of leaders without an ethnic army did attempt to ignore or alter their constitutions, a non-trivial rate of defiance, a remarkable $82 \%$ of presidents backed by an ethnic army took up the same mantle. Indeed, in only one country did prior ethnic stacking not lead to term limit challenges: both Presidents Moi (2002) and Kibaki (2012) respected Kenya's two-term limit despite having disproportionately recruited Kalenjin and Kikuyu, respectively, into the higher echelons of the officer corps ${ }^{36}$ Apart from apparent Kenyan exceptionalism, ethnic armies strongly encourage leaders to defy their constitutions.

[Table 2 about here] 
This relationship seems to hold when considering other theoretically relevant variables. In their analysis, Posner and Young find that both oil production and prior respect for term limits meaningfully shape whether a leader seeks to unconstitutionally extend their time in office. Oil revenues make leaders less dependent on both external aid and domestic taxes, potentially undermining sources of pressure to respect the constitution. A precedent of abiding by term limits, on the other hand, may entrench democratic norms and encourage future leaders to do the same. Other variables they consider - including the president's age, vote share and victory margin in the prior election, and foreign aid — were not significant, even in bivariate comparisons between sample means. ${ }^{37}$

Table 3 presents a bivariate coefficient matrix for the three most theoretically relevant independent variables and the dependent variable. An ethnic army and oil wealth are both positively correlated with term limit defiance while a precedent of observing term limits is negatively correlated with future challenges. None of the independent variables are correlated with each other, however, in a statistically significant manner. While only suggestive, this series of bivariate results indicates that the effect of an ethnic army is not merely reducible to another variable. Unfortunately, the dataset is too small to conduct regression analysis, even between a limited number of variables, and is certainly too small to include interaction terms or a full set of controls.

[Table 3 about here] 
In addition to influencing which presidents seek to defy their term limits, ethnic armies enhance their chances of success (see Table 4). With the exception of Malawi's Muluzi, every leader backed by coethnic security institutions who tried was able to alter or ignore their constitution and embark on a third term in office. In contrast, leaders without an ethnic army failed to extend their tenure $75 \%$ of the time. This relationship is strong and statistically significant: a coethnic army more than triples the predicted probability, from roughly $28 \%$ to $85 \%$, of a president successfully defying his term limits.

Closer analysis of the two exceptions, where presidents succeeded despite commanding diverse militaries, lends further support to the theorized mechanism. First, President Nkurunziza of Burundi attempted to defy his term limits against the back drop of a diverse military created through a peace agreement, integrating the state's former Tutsi dominated army with Hutu rebel soldiers. As previously discussed, Nkurunziza miscalculated his military's loyalty and a faction of it attempted to overthrow him. He thus prevailed in extending his rule against long odds that probably should have deterred him from seeking a third term in the first place. Indeed, overt interventions by at least some part of the armed forces to prevent a leader from defying the constitution only occurred where militaries had not been previously ethnically stacked: in Burkina Faso, Burundi, and Niger (emphasized in bold in Table 4).

Second, President Sam Nujoma was able to alter Namibia's constitution and successfully run for a third term in 1999. Like Nkurunziza, Nujoma also commanded a diverse national military created in the aftermath of war by integrating the victorious, and largely Ovambo, rebel army with the ethnic battalions of the South African-backed territorial military. ${ }^{38}$ Despite not benefitting from an ethnically loyal army, he was nonetheless able to count on deep and abiding 
military loyalty. Nujoma was a war hero and a lauded figure in Namibia's struggle for independence against apartheid South Africa. He thus enjoyed high levels of personal legitimacy and loyalty both within Namibia's military and across society; loyalty he could rely on in the unlikely event that opposition emerged to his further rule.

Existing alternative theories do not seem to carry much explanatory value. Unlike military loyalty, mass mobilization does not systematically influence whether term limit challenges are successful, as Yarwood has suggested. ${ }^{39}$ While widespread protests have been significant in cases like Burkina Faso and Senegal, they have been equally insignificant in contexts such as Cameroon and Congo-Brazzaville. Indeed, of the cases in which mass mobilization arose, presidents still successfully defied term limits exactly half of the time, producing a statistically insignificant and substantively meaningless correlation (see Table A2 in the Online Appendix). Breaking the cases down further suggests that military loyalty may actually condition when mass mobilization works: where civil resistance emerged, it always failed to check the presidents backed by ethnic armies (in Cameroon 2011, Congo-Brazzaville 2016, and Djibouti 2011) and yet succeeded in stopping presidents who commanded diverse militaries $80 \%$ of the time (in Benin 2016, Burkina Faso 2015, Senegal 2012, and Zambia 2001, with Burundi 2015 the exception).

The cross-national data thus lend compelling support to the theory developed: coethnic armies greatly increase the probability that a leader can defy their term limits and extend their hold on power, encouraging those leaders to make the attempt. 


\section{Paired Case Comparison: Cameroon and Senegal}

Cameroon and Senegal are broadly comparable cases of patronage-based authoritarian regimes that both faced intense liberalization pressures in the 1990's, leading to competitive multiparty elections. They have since followed divergent trajectories with Senegal embarking on a path of increasing democratization, especially following Wade's failed bid to defy constitutional term limits. Cameroon, by contrast, has remained stubbornly autocratic under long-ruling President Biya, who has successfully nullified any restrictions to indefinitely seeking reelection. A critical factor underlying these different paths has been the degree to which each leader could rely on the unwavering loyalty of their security institutions to repress dissent. Biya has routinely employed his coethnic army to dampen opposition and maintain his hold on power, while Senegal's leaders command an ethnically diverse military who have shown through defection that their primary loyalty lies with the constitution.

\section{Senegal}

Abdoulaye Wade was Senegal's first democratically elected President, following four decades of single party, authoritarian rule. Although he initially furthered liberalization efforts, Wade soon began reversing these trends and retrenching past autocratic practices, culminating in his bid to defy the constitution's two term limit and cling to power. Facing military defection by a diverse army not personally loyal to him, mass demonstrations and protests, and defeat at the polls, Wade peacefully handed power over to his elected successor, ultimately furthering Senegal's democratization. 
Following independence, Senegal was governed as an autocratic single party state that relied extensively on patronage to induce mass support. Agricultural subsidies and privileges in the groundnut export sector were granted to the leaders of Senegal's Sufi brotherhoods in exchange for edicts commanding their followers to vote for the governing party. ${ }^{40}$ Economic crisis in the 1980's led to structural adjustment programs, mandating deep cuts in agricultural funding that undermined these patron-client networks. The brotherhoods ceased issuing their edicts and, facing added pressure from both donors and street protests, the government began liberalizing and adopted a more transparent electoral code. These efforts culminated in the watershed presidential election of 2000 in which Abdoulaye Wade defeated the long-ruling incumbent government. ${ }^{41}$

Although Wade initially improved Senegal's human rights record and oversaw the adoption of a new, more liberal constitution, his flirtation with democracy soon faltered. His 2007 reelection bid was marred by manipulations and irregularities. He also began exhibiting worrying authoritarian tendencies, increasingly concentrating power in the presidency. Wade packed state institutions, including the judiciary and the upper house of parliament, with political loyalists and personalized his rule by appointing kin to important ministerial portfolios. Violations of civil liberties also increased, including political intimidation, police repression of protests, and the detention of journalists and opposition leaders. ${ }^{42}$

These autocratic moves culminated in Wade's attempt to cling to power. In May 2011, he officially announced his intention to run for an unconstitutional third term in office. Packed with sympathetic judges dependent on Wade's favor, the Constitutional Court ruled in his favor despite the clear legal violation. He then submitted a bill to parliament which would have 
reduced the vote share needed to win in the first round of elections, from $50 \%$ to $25 \%$, making it far easier for Wade to overcome the fractured opposition. ${ }^{43}$ Through quasi-legal maneuvering, Wade thus threatened to undo Senegal's tenuous democratic gains and cement autocratic rollback.

Unlike many of his contemporaries, Wade did not benefit from an ethnically loyal army. Quite to the contrary, Senegal's military has always been diverse. Senegal's independence leader and long-serving first president, Léopold Senghor, believed wholeheartedly that inclusion and protection of the country's diverse ethnic and tribal communities was central to building strong institutions and a sense of nationalism. He thus recruited soldiers and officers broadly across ethnic communities, a tradition that was upheld by subsequent leaders. ${ }^{44}$ Wade thus could not rely on the loyalty mechanisms that tie soldiers to the fate of leaders when they are recruited on an ethnic basis. The absence of such personal loyalty not only facilitated the army's ultimate defection, but may also have contributed to mass protests and strong opposition voter mobilization. Wade could not count on the military to repress and thus could not prevent the resistance he encountered.

Indeed, Wade's bid to defy term limits failed miserably: civil society mobilized against him, he was defeated at the polls, and the military abandoned him. After Wade's reelection, a coalition of opposition leaders and NGOs traveled the country, visiting each of Senegal's administrative departments to consult with ordinary citizens on the many social, economic, and political problems facing the country. Out of this effort a new opposition movement was formed, the United to Boost Senegal coalition, which successfully defeated Wade's party in the 2009 local elections. Additional popular movements also coalesced in opposition to Wade, including 
Y'en a Marre (Enough is Enough) and Bes du Ñiakk (Citizen's Movement for National Refoundation). As Wade attempted to secure his third term in office, these movements organized mass protests in Dakar and other urban areas, forcing the withdrawal of his vote threshold lowering bill. This victory, in turn, inspired the June 23 Movement, comprised of 60 NGOs and opposition parties who sought to prevent Wade from winning the presidential elections. ${ }^{45}$

Wade lost, and lost badly, at the polls. He only garnered $32 \%$ of votes in the first round, falling well short of the required 50\%. The opposition then united in support of Macky Sall, resulting in a pronounced defeat for Wade in the second round of voting: $34.2 \%$ to $65.8 \% .{ }^{46}$ While Senegal's energized civil society played an important role in ensuring free and fair elections,${ }^{47}$ the military also helped ensure a peaceful transfer of power by peremptorily defecting from the regime. Having conducted their own opinion surveys, the military informed Wade of his impending loss soon after the polls closed-and lack of security sector support if he tried to defy the election results. Wade then quickly conceded defeat. Subsequent legislative elections saw Sall's United in Hope coalition win 119 of 150 seats in the National Assembly, thoroughly removing Wade's political party from power. ${ }^{48}$

\section{Cameroon}

Paul Biya inherited the presidency of Cameroon in 1982, when the country's first longserving leader retired for health reasons. Despite economic malaise, Biya's authoritarian regime has withstood intense pressures for democratization, including a civil resistance campaign and a brief, failed spell of real multiparty competition in the 1990's. Biya is supported both by a personally loyal parliament and by an ethnically loyal military, institutions that have allowed him 
to alter laws and repress dissent with ease. In 2011, Biya successfully nullified the constitution's term limits and won reelection to his sixth term in office.

As in Senegal, following independence, Cameroon was governed by a single-party state that maintained extensive patronage networks to garner popular support. Both Ahmadou Ahidjo, Cameroon's first President, and Biya employed a sophisticated "ethnic arithmetic" in the distribution of state resources to ensure widespread cooptation. Ethnic and regional leaders were appointed as ministers, legislators, and managers of state owned enterprises on the basis of personal loyalty; positions that secured access to funds and projects that could then be distributed amongst their clients and within their homelands. ${ }^{49}$

Unlike in Senegal, however, coethnic security institutions undergirded this system of patronage-based cooptation. During and immediately following decolonization, Ahidjo disproportionately recruited fellow northern, Muslim Fulani and Peuhl into both the army and an elite paramilitary republican guard. ${ }^{50}$ After assuming power, Biya, who hails from the southern, Christian Bulu, announced his intentions to restructure these institutions, prompting a reactionary coup attempt. Capitalizing on the failed coup, Biya dissolved the republican guard, purged northerners from the ranks, and employed discriminatory recruitment and promotion practices of his own. Southerners, and particularly the Bulu clans and larger Beti ethnic group of which they form a part, came to dominate the military and hold critical command positions within the officer corps. $^{51}$

Biya's ethnic army has played a fundamental role in ensuring his regime's survival and resistance to democratization. After the end of the Cold War, external influences, economic malaise, and internal protests conspired to generate significant pressures for liberalization. 
Opération Villes Mortes (or Operation Ghost Town), a civil resistance campaign that attempted to completely shut down urban areas until the government permitted a constitutional conference and a full democratic transition, was the most significant of these pressures. Despite substantial national participation, however, the movement never posed a serious risk to regime stability nor did any threat of military insubordination emerge. There would be no constitutional conference and no alternation of executive power. Competitive multi-party elections were permitted in 1992, but Biya and his party managed to eke out a win and then reconsolidate their dominance. Throughout this period, Biya extensively used his coethnic military to crack down on demonstrators and repress the democratic opposition. ${ }^{52}$ Indeed, Gros writes that "the support of the military and the security forces for the Biya government was probably the single most important domestic factor behind the failure of transition to multiparty politics." ${ }^{\prime 3}$

Despite this failed transition, liberalization pressures did succeed in adding presidential term limits to the constitution; limits that threatened to end Biya's long rule. Their nullification, however, proved an easy obstacle to overcome. Through long-standing practices of voter disenfranchisement and suppression, combined with gerrymandering electoral districts to vastly increase the number of legislators hailing from his traditional strongholds, Biya had assured himself strong influence over parliament. Since 2002, his party has controlled over $4 / 5$ of the seats. An overwhelmingly affirmative vote from parliament abolished the constitutional term limits in April 2008, after only a couple months of deliberation. ${ }^{54}$ Nor did popular resistance pose much of an obstacle. The proposed amendment, along with rising food and fuel prices, did spark the largest mass protests that Cameroon had witnessed since Opération Villes Mortes. However, they were handily repressed by the security sector, and the riot police in particular, with over 100 
killed and 1500 arrested in February 2008. ${ }^{55}$ Subsequently, in 2011, without facing renewed mass protests, Biya won reelection to his sixth term in office by a self-reported, and likely fraudulent, landslide victory of $78 \%$ of the vote..$^{56}$

\section{Conclusions}

The military plays a fundamental and yet under-appreciated role in undermining or furthering democratization in Africa. Beyond direct interference in the form of coups, military loyalty more subtly conditions the political trajectory of states. Leaders who can rely on unwavering military loyalty in the event of domestic unrest face fewer risks and greater chances of success in rolling back liberalization and entrenching authoritarian practices. Tying soldiers to the fate of their leaders through ethnic favoritism is a profoundly powerful way to build such reliable military loyalty. With respect to challenging term limits, this article has demonstrated that ethnic armies enable leaders to triple their odds of defying constitutions and extending their hold on power. Such high success rates encourage defiance in the first place, with a remarkable $82 \%$ of presidents backed by ethnic armies attempting to ignore or alter their term limits, as opposed to $31 \%$ of other leaders. Through their loyalty, ethnic armies thus undermine liberalization by encouraging presidential consolidation of power.

These findings suggest important policy recommendations. The long-term survival and entrenchment of democracy in Africa requires military reform in those countries still maintaining ethnic armies. Merit must replace personal and ethnic loyalty as the foundation for military recruitment, retention, and promotion practices. Such ethnically diverse and merit-based militaries, or at least factions of them, are far more likely to defect from leaders attempting to 
rollback liberal gains, refusing to repress or intervening directly against them. In such contexts, civil society, legislatures, opposition parties, and even dissenting politicians within the ruling party, have a greater chance of succeeding in their defense of constitutionalism, furthering democratization.

Of course, it is those leaders reliant on ethnic loyalty to sustain their power who are least likely to initiate reforms. Even where there is the political will for military restructuring, meritbased reform is no easy task and will likely inspire resistance from officers whose privileged position is now threatened. Both difficult to dislodge and directly enabling presidential consolidation of power, ethnic armies may thus directly contribute to the already noted divergent trajectories of African states: those experiencing virtuous cycle of liberalization and good governance versus those that have fallen into a vicious cycle of deepening authoritarianism. 


\section{Bibliography}

Barany, Zoltan. "Comparing the Arab Revolts: The Role of the Military." Journal of Democracy 22, no. 4 (2011): 24-35.

Barany, Zoltan. "Democratic Consolidation and the Military: The East European Experience." Comparative Politics 30, no. 1 (1997): 21-43.

Beblawi, Hazem, and Giacomo Luciani, eds. The Rentier State. New York: Routledge, 2015.

Bratton, Michael, and Nicolas van de Walle. Democratic Experiments in Africa. Cambridge: Cambridge University Press, 1997.

Carter, Brett L. "How International Pressure Can Help.” Journal of Democracy 27, no. 3: 36-50.

Chenoweth, Erica, and Maria Stephan. "Why Civil Resistance Works: The Strategic Logic of Nonviolent Conflict." International Security 33, no. 1 (2008): 7-44.

Chenoweth, Erica, and Maria Stephan. Why Civil Resistance Works: The Strategic Logic of Nonviolent Conflict. New York: Columbia University Press, 2012.

Clark, Andrew F. "Imperialism, Independence, and Islam in Senegal and Mali." Africa Today 46, no. 3/4 (1999): 149-167.

Clark, John F. "The Decline of the African Military Coup." Journal of Democracy 18, no. 3 (2007): 141-155.

Collier, Paul. "Let Us Now Praise Coups.” The Washington Post, June 22, 2008.

Dahou, Tarik, and Vincent Foucher. "Senegal since 2000: Rebuilding Hegemony in a Global Age." In Turning Points in African Democracy, edited by Abdul Raufu Mustapha and Lindsay Whitfield, 13-49. Suffolk: James Currey, 2009.

De Bruin, Erica. "Preventing Coups d’État: How Counterbalancing Works." Working Paper.

Decalo, Samuel. Civil-Military Relations in Africa. Gainesville: Florida Academic Press, Inc., 1998.

DeLancey, Mark W. "The Construction of the Cameroon Political System: The Ahidjo Years, 1958-1982." Journal of Contemporary African Studies 6, no. 1-2 (1987): 3-24.

Diamond, Larry. "Facing Up to the Democratic Recession." Journal of Democracy 26, no. 1 (2015): 141-155. 
Diop, Momar Coumba, and Moussa Paye. "The Army and Political Power in Senegal." In The Military and Militarism in Africa, edited by Eboe Hutchful and Abdoulaye Bathily, 315-354. Dakar, Senegal: CODESRIA, 1998.

Dulani, Boniface. “African Publics Strongly Support Term Limits, Resist Leaders' Efforts to Extend Their Tenure.” Afrobarometer Dispatch no. 30 (2015): 1-12.

The Economist. "Lucky Macky: Senegal Retains Its Title as Africa's Oldest Democracy.” April 7, 2015.

Eizenga, Daniel. "Burkina Faso Elections Mark Turning Point In Country’s Recent Political Turmoil." The Washington Post, December 6, 2015.

Enloe, Cynthia H. Ethnic Soldiers: State Security in Divided Societies. Athens: University of Georgia Press, 1980.

Fatton, Jr., Robert. "Clientalism and Patronage in Senegal.” African Studies Review 29, no.4 (1986): 61-78.

Fessy, Thomas. "How Burkina Faso's Blaise Compaore Sparked His Own Downfall.” BBC. October 31, 2014.

Freedom House. "Burkina Faso.” In Freedom in the World. Annual Reports, 2011-2015. https:// freedomhouse.org/country/burkina-faso.

Freedom House. "Burundi." In Freedom in the World. Annual Reports, 2014-2016. https:// freedomhouse.org/country/burundi.

Freedom House. “Cameroon.” In Freedom in the World. Annual Reports, 2014-2016. https:// freedomhouse.org/country/cameroon.

Freedom House. Freedom in the World 2016. Annual Report, 2016. https://freedomhouse.org/ report/freedom-world/freedom-world-2016.

Freedom House. "Senegal." In Freedom in the World. Annual Reports, 1999-2015. https:// freedomhouse.org/country/senegal.

Galvan, Dennis. "Political Turnover and Social Change in Senegal." Journal of Democracy 12, no.3 (2001): 51-62.

Goldsworthy, David. "Civilian Control of the Military in Black Africa." African Affairs 80, no. 318 (1981): 49-74. 
Gros, Jean-Germain. "The Hard Lessons of Cameroon.” Journal of Democracy 6, no. 3 (1995): 112-126.

Gürsoy, Yaprak. "The Changing Role of the Military in Turkish Politics: Democratization through Coup Plots?" Democratization 19, no. 4 (2012): 735-760.

Hagopian, Frances. “'Democracy by Undemocratic Means?’ Elites, Political Pacts, and Regime Transition in Brazil.” Comparative Political Studies 23, no. 2 (1990): 147-170.

Hale, Henry E. The Foundations of Ethnic Politics: Separatism of States and Nations in Eurasia and the World. Cambridge: Cambridge University Press, 2008.

Harkness, Kristen A. "The Ethnic Army and the State: Explaining Coup Traps and the Difficulties of Democratization in Africa." Journal of Conflict Resolution 60, no. 4 (2016): 587-616.

Harkness, Kristen A. "Security Assistance in Africa: The Case for More. Parameters 45, no. 2 (2015): 13-24.

Henshaw, Drew. “Burkina Faso's Military Coup Overturned.” The Wall Street Journal, September 23, 2015.

Hornsby, Charles. Kenya: A History Since Independence. London: I.B. Tauris \& Co Ltd, 2013.

Human Rights Watch. "Burundi: Abductions, Killings, Spread Fear.” February 25, 2016.

Human Rights Watch. "Burundi: Deadly Police Response to Protest.” May 29, 2015.

Human Rights Watch. "Burundi: President's Speech Instills Fear as Killings Increase." November 10, 2015.

Human Rights Watch. "Burundi: Spate of Arbitrary Arrests, Torture.” August 6, 2015.

Keegan, John. World Armies. Detroit, Michigan: Gale Research Company, 1983.

Kelly, Catherine Lena. “Senegal: What Will Turnover Bring?” Journal of Democracy 23, no. 3 (2012): 121-131.

Konings, Piet. "The Post-Colonial State and Economic and Political Reforms in Cameroon." In Liberalization in the Developing World: Institutional and Economic Changes in Latin America, Africa, and Asia, edited by Alex E. Fernández Jilberto and André Mommen, 244-265. London and New York: Routledge, 1996. 
Leys, Colin, and John S. Saul. Namibia's Liberation Struggle: The Two-Edged Sword. Suffolk, United Kingdom: James Currey, 1995.

Lindberg, Staffan I., and John F. Clark. "Does Democratization Reduce the Risk of Military Interventions in Politics in Africa?" Democratization 15, no. 1 (2008): 86-105.

Luckham, Robin. "Democracy and the Military: An Epitaph for Frankenstein's Monster?" Democratization 3, no.2 (1996): 1-16.

Mail and Guardian. "Burundi Crisis Spreads Outside the Capital; Army 'Purge' Underway Following Failed Coup.” June 6, 2015.

Maltz, Gideon. "The Case for Presidential Term Limits." Journal of Democracy 18, no. 1 (2007): 128-142.

Marinov, Nikolay, and Hein Goemans. "Coups and Democracy." British Journal of Political Science 44, no. 4 (2014): 799-825.

Markovitz, Irving Leonard. Léopold Sédar Senghor and the Politics of Negritude. New York: Atheneum, 1969.

Minorities at Risk Project. "Minorities at Risk Dataset" (accessed August 1,2016). http:// www.cidem.umd.edu/mar.

N'Diaye, Boubacar. The Challenge of Institutionalizing Civilian Control: Borswana, Ivory Coast, and Kenya in Comparative Perspective. Oxford: Lexington Books.

Nelson, Harold. Area Handbook for Senegal (2nd ed.). Washington, D.C.: American University, 1974.

Niyungeko, Sadi, and Dan Bilefsky. "Burundi Government Says It Has Crushed Coup Attempt." The New York Times, May 15, 2015.

Nunley, Alfred C. “African Elections Database” (accessed February 28, 2016). http:// africanelections.tripod.com/index.html.

O’Donnell, Guillermo, and Philippe C. Schmitter. Transitions from Authoritarian Rule: Tentative Conclusions about Uncertain Democracies. Baltimore: Johns Hopkins University Press, 1986.

Opalo, Kennedy Ochieng' “African Elections: Two Divergent Trends.” Journal of Democracy 23, no. 3 (2012): 80-93. 
Posner, Daniel N., and Daniel J. Young. "Term Limits and the Transfer of Power." In Politics in Africa: The Importance of Institutions, edited by Nicholas Cheeseman. New York: Cambridge University Press, Forthcoming.

Powell, Jonathan M., Christopher Faulkner, William Dean, and Kyle Romano. "Give Them Toys: Military Allocations and Regime Stability in Transitional Democracies.” Working Paper.

Riedl, Rachel Beatty. "The Advantages — and Drawbacks — of Presidential Term Limits as a Tool for Building Democracy in Africa.” Scholars Strategy Network: Key Findings, March.

Ross, Michal L. “Does Oil Hinder Democracy?” World Politics 53, no. 3 (2001): 325-361.

Ross, Michael L. “The Political Economy of the Resource Curse.” World Politics 51, no. 2 (1999): 297-322.

Shah, Aqil. "Constraining Consolidation: Military Politics and Democracy in Pakistan, 2007-2013.” Democratization 21, no. 6 (2014): 1007-1033.

Ssuuna, Ignatius, and Eloge Willy Kaneza. "Burundi Army Defections Show Dangerous Ethnic Divisions." Associated Press, December 30, 2015.

Svolik, Milan W. "Contracting on Violence: The Moral Hazard in Authoritarian Repression and Military Intervention in Politics.” Journal of Conflict Resolution 57, no. 5 (2012): 765-794.

Svolik, Milan W. The Politics of Authoritarian Rule. Cambridge: Cambridge University Press, 2012.

Takougang, Joseph. "The Post-Ahidjo Era in Cameroon: Continuity and Change." Journal of third World Studies 10, no. 2 (1993): 268-302.

Takougang, Joseph. "The Nature of Politics in Cameroon." In The Leadership Challenge in Africa: Cameroon under Paul Biya, edited by John Mukum Mbaku and Joseph Takougang, 67-94. Trenton, New Jersey: Africa World Press, 2003.

Taoko, Hervé, Alan Cowell, and Rukmini Callimachi. "Violent Protests Topple Government in Burkina Faso." The New York Times, October 30, 2015.

The Telegraph. "Burkina Faso Coup_As It Happened.” September 17, 2015.

Thyne, Clayton L., and Jonathan M. Powell. "Coup d'État or Coup d'Autocracy? How Coups Impact Democratization, 1950-2008.” Foreign Policy Analysis (Forthcoming). 
Tusalem, Rollin F. "Bringing the Military Back In: The Politicisation of the Military and Its Effect on Democratic Consolidation." International Political Science Review (Forthcoming).

Villalón, Leonardo A. "Cautious Democrats: Religious Actors and Democratization Processes in Senegal." Politics and Religion 8, no. 2 (2015): 305-333.

Vircoulon, Thierry. "Insights from the Burundian Crisis (I): An Army Divided and Losing Its Way." International Crisis Group, October 2, 2015.

Yarwood, Janette. “The Power of Protest." Journal of Democracy 27, no. 3 (2016): 51-60.

Wobig, Jacob. "Defending Democracy with International Law: Preventing Coup Attempts with Democracy Clauses." Democratization 22, no. 4 (2015): 631-654. 
Table 1: Term Limit Challenges in Africa, 1990-2016

\begin{tabular}{|c|c|c|}
\hline \multicolumn{3}{|c|}{ Two-Term Limit Reached } \\
\hline \multirow[t]{2}{*}{ Limit Accepted } & \multicolumn{2}{|c|}{ Attempt to Ignore Limit or Amend Constitution } \\
\hline & Successful & Failed \\
\hline $\mathrm{n}=19$ & $\mathrm{n}=11$ & $n=7$ \\
\hline $\begin{array}{c}\text { Benin (Kerekou 2006) } \\
\text { Botswana (Moage 2008) } \\
\text { Cape Verde (Montiero 2001) } \\
\text { Ghana (Rawlings 2000) } \\
\text { Ghana (Kufuor 2008) } \\
\text { Kenya (Moi 2002) } \\
\text { Kenya (Kibaki 2012) } \\
\text { Mali (Konaré 2002) } \\
\text { Mali (Touré 2012) } \\
\text { Mozambique (Chissano 2004) } \\
\text { Mozambique (Guebuza 2014) } \\
\text { Namibia (Nujoma 2004) } \\
\text { Namibia (Pohamba 2014) } \\
\text { São Tomé (Trovoada 2001) } \\
\text { São Tomé (Menezes 2011) } \\
\text { Sierra Leone (Kabbah 2007) } \\
\text { Tanzania (Mwinyi 1995) } \\
\text { Tanzania (Mkapa 2005) } \\
\text { Tanzania (Kikwete 2015) }\end{array}$ & $\begin{array}{c}\text { Burundi (Nkurunziza 2015) } \\
\text { Cameroon (Biya 2011) } \\
\text { Chad (Deby 2006) } \\
\text { Congo-B (Sassou-Nguessou 2016) } \\
\text { Djibouti (Guelleh 2011) } \\
\text { Gabon (Bongo 2005) } \\
\text { Guinea (Conté 2003) } \\
\text { Namibia (Nujoma 1999) } \\
\text { Sudan (Bashir 2005) } \\
\text { Togo (Eyadema 2003) } \\
\text { Uganda (Museveni 2006) }\end{array}$ & $\begin{array}{c}\text { Benin (Boni Yayi 2016) } \\
\text { Burkina Faso (Campoaré 2015) } \\
\text { Malawi (Muluzi 2004) } \\
\text { Niger (Tandja 2009) } \\
\text { Nigeria (Obasanjo 2007) } \\
\text { Senegal (Wade 2012) } \\
\text { Zambia (Chiluba 2001) }\end{array}$ \\
\hline
\end{tabular}

Table 2: How Military Loyalty Shapes the Decision to Challenge Term Limits

\begin{tabular}{|l|c|c|c|}
\hline & \multicolumn{3}{|c|}{ Presidential Challenge to Term Limits? } \\
\hline \multirow{2}{*}{ Ethnic Army? } & yes & yes & no \\
\hline & no & 9 & 2 \\
\hline & 8 & 18 \\
\hline
\end{tabular}

Note: missing cases $=$ Sudan 2005 (Bashir); bivariate correlation $=0.47 ; X^{2}=6.19(p \leq 0.05)$; bivariate logit (challenge $\sim$ ethnic army) $=2.32(p \leq 0.01)$. 
Table 3: Bivariate Coefficient Matrix for the Determinants of Term Limit Challenges

\begin{tabular}{|c|c|c|c|c|}
\hline & Ethnic Army & Oil Producer & Precedent & Challenge \\
\hline Ethnic Army & - & 1.4773 & -1.6666 & $2.3150^{\star *}$ \\
\hline Oil Producer & & - & -0.9445 & $2.338^{*}$ \\
\hline Precedent & & & - & $-2.5719^{*}$ \\
\hline Challenge & & & \\
\hline
\end{tabular}

Table 4: How Military Loyalty Shapes the Outcome of Term Limit Challenges

\begin{tabular}{|c|c|c|c|}
\hline & \multicolumn{3}{|c|}{ Outcome of Term Limit Challenge } \\
\hline \multirow{3}{*}{ Ethnic Army? } & & success & failure \\
\hline & yes & $\begin{array}{c}\text { Cameroon (Biya 2011) } \\
\text { Chad (Deby 2006) } \\
\text { Congo-B (Sassou-Nguessou 2016) } \\
\text { Djibouti (Guelleh 2011) } \\
\text { Gabon (Bongo 2005) } \\
\text { Guinea (Conté 2003) } \\
\text { Togo (Eyadema 2003) } \\
\text { Uganda (Museveni 2006) }\end{array}$ & Malawi (Muluzi 2004) \\
\hline & no & $\begin{array}{l}\text { Burundi (Nkurunziza 2015) } \\
\text { Namibia (Nujoma 1999) }\end{array}$ & $\begin{array}{c}\text { Benin (Boni Yayi 2016) } \\
\text { Burkina Faso (Campoaré 2015) } \\
\text { Niger (Tandja 2009) } \\
\text { Nigeria (Obasanjo 2007) } \\
\text { Senegal (Wade 2012) } \\
\text { Zambia (Chiluba 2001) }\end{array}$ \\
\hline lote: missin & & $\begin{array}{l}5 \text { (Bashir); bivariate correlation } \\
.18(p \leq 0.05) \text {; coup attempts ir }\end{array}$ & $55 ; X^{2}=4.74(\mathrm{p} \leq 0.05) ;$ bivariate \\
\hline
\end{tabular}


${ }^{1}$ I would like to thank Aedan Collins and Kirsty MacIntosh for research assistance. I would also like to thank Aurel Croissant, Michael Hunzeker, David Kuehn, Alexander Lanoszka, and two anonymous reviewers for feedback on prior drafts.

${ }^{2}$ Democracy is a heavily contested concept. I focus instead on liberalization or democratization, terms that denote the transition away from authoritarian practices toward greater respect for political, civil, and human freedoms.

${ }^{3}$ Bratton and van de Walle, Democratic Experiments in Africa, 10.

${ }^{4}$ Freedom House, Freedom in the World 2016. Larry Diamond argues that 25 democracies have broken down since 2000, with 32\% of these in Africa. Diamond, "Facing Up to the Democratic Recession," 144.

${ }^{5}$ Other studies reverse the relationship and analyze the effect of democratization on coups, largely arguing that increased liberalization diminishes the frequency of coup attempts. See Clark, "The Decline of the African Military Coup"; Lindberg and Clark, "Does Democratization Reduce the Risk of Military Interventions"; and Wobig, "Defending Democracy with International Law." Additionally, a literature with older roots, focused primarily on Latin America and Southern Europe but with extensions to other regions, analyzed the conditions under which military regimes could be coaxed out of power via pacted transitions and the consequences of these pacts, which often included amnesty provisions and an institutionalized political voice for the military, on democratic consolidation. See Barany, "Democratic Consolidation and the Military"; Hagopian, "Democracy by Undemocratic Means?"; Luckham, "Democracy and the Military"; O’Donnell and Schmitter, Transitions from Authoritarian Rule, 39-40; and Shah, "Constraining Consolidation."

${ }^{6}$ Collier, "Let Us Now Praise Coups."

7 Thyne and Powell, "Coup d'État or Coup d'Autocracy?"

${ }^{8}$ Marinov and Goemans, "Coups and Democracy."

${ }^{9}$ Gürsoy, "The Changing Role of the Military in Turkish Politics."

10 Tusalem, "Bringing the Military Back In."

${ }^{11}$ Harkness, "Ethnic Army and the State."

12 Yarwood, "The Power of Protest," 51.

${ }^{13}$ See Carter, "How International Pressure Can Help," 38-41; Maltz, "The Case for Presidential Term Limits"; Posner and Young, "Term Limits and the Transfer of Power," 12-13; and Riedl, "The Advantages — and Drawbacks —of Presidential Term Limits."

${ }^{14}$ Replicated from Posner and Young, "Term Limits and the Transfer of Power," 20, with the following missing cases added: Benin (Boni Yayi 2016) and Senegal (Wade, 2012), both of which were failed attempts to defy term limits.

${ }^{15}$ Posner and Young, Term Limits and the Transfer of Power.

${ }^{16}$ Freedom House, "Burundi"; Human Rights Watch, "Deadly Police Response to Protests"; and Niyungeko and Bilefsky, "Burundi Government Says It Has Crushed Coup Attempt."

${ }^{17}$ Freedom House, "Burundi"; Human Rights Watch. "Abductions, Killings, Spread Fear"; Human Rights Watch, "President's Speech Instills Fear"; Human Rights Watch, "Spate of Arbitrary Arrests, Torture"; Mail and Guardian, "Burundi Crisis Spreads Outside the Capital"; Ssuuna and Kaneza, "Burundi Army Defections Show Dangerous Ethnic Divisions"; and Vircoulon, "Insights from the Burundian Crisis."

${ }^{18}$ Eizenga, "Burkina Faso Elections Mark Turning Point”; Fessy, "How Burkina Faso's Blaise Compaore Sparked His Own Downfall”; Freedom House, "Burkina Faso"; Henshaw, "Burkina Faso's Military Coup Overturned"; Taoko et al., "Violent Protests Topple Government in Burkina Faso"; and The Telegraph, "Burkina Faso Coup-As It Happened." 
${ }^{19}$ Dulani, “African Publics Strongly Support Term Limits,” 3.

20 Posner and Young, "Term Limits and the Transfer of Power," 8.

${ }^{21}$ Svolik, Politics of Authoritarian Rule, 2.

22 Ibid, 10.

${ }^{23}$ Svolik, "Contracting on Violence," 767; and Svolik, Politics of Authoritarian Rule, 125-127.

${ }^{24}$ Chenoweth and Stephan, Why Civil Resistance Works, 46-50; and Chenoweth and Stephan, "Why Civil Resistance Works," 13.

${ }^{25}$ Barany, "The Role of the Military."

${ }^{26}$ De Bruin, "Preventing Coups d'État."

27 Powell et al., "Give Them Toys."

${ }^{28}$ Harkness, "The Ethnic Army and the State."

${ }^{29}$ Adekson, "Army in a Multi-Ethnic Society," 154; and Young, The African Colonial State in Comparative Perspective, 105-106.

${ }^{30}$ Harkness, "The Ethnic Army and the State," 592-593. See also Decalo 1998, Civil-Military Relations in Africa; Enloe, Ethnic Soldiers; Goldsworthy, "Civilian Control of the Military in Black Africa"; and Harkness, "Security Assistance in Africa."

${ }^{31}$ Hale, The Foundations of Ethnic Politics, 33-40.

32 See Beblawi and Luciani, The Rentier State; Ross, "Does Oil Hinder Democracy?"; and Ross "The Political Economy of the Resource Curse."

${ }^{33}$ Posner and Young, "Term Limits and the Transfer of Power," Table 1.

${ }^{34}$ Harkness, "The Ethnic Army and the State," 594.

35 This is a rough measurement instrument that cannot distinguish between degrees of ethnic stacking across leaders. While more fine grained data is desirable, the contemporary time frame of analysis means that internal military and other archival records remain classified, precluding its collection.

${ }^{36}$ N'Diaye, The Challenge of Institutionalizing Civilian Control, 130-131; and Hornsby, Kenya: A History Since Independence, 712-713.

${ }^{37}$ Posner and Young, "Term Limits and the Transfer of Power."

${ }^{38}$ Leys and Saul, Namibia's Liberation Struggle, 58.

39 Yarwood, "The Power of Protest."

40 Clark, "Imperialism, Independence, and Islam," 160; and Fatton, "Clientalism and Patronage in Senegal."

${ }^{41}$ Galvan, "Political Turnover and Social Change," 59; Nunley, “African Elections Database”; and Villalón, "Cautious Democrats," 312.

42 Dahou and Foucher, "Senegal since 2000," 21; Freedom House, "Senegal”; and Kelly, "Senegal: What Will Turnover Bring?," 121.

${ }^{43}$ Kelly, "Senegal: What Will Turnover Bring?," 127-128.

${ }^{44}$ Diop and Paye, "The Army and Political Power in Senegal," 319; Keegan, World Armies, 514-515; Markovitz, Léopold Sédar Senghor and the Politics of Negritude, 111-113; and Nelson, Area Handbook for Senegal, 340. 
${ }^{45}$ Ibid, 126-128.

${ }^{46}$ Freedom House, "Senegal."

${ }^{47}$ For example, observers were despatched to over 11,000 polling stations to observe the proceedings and textmessage vote counts to volunteer collation centers in Dakar. In this way, civil society activists and journalists could monitor local vote counts and observe any attempts to alter tallies as the votes were aggregated. The Economist, "Lucky Macky."

${ }^{48}$ Ibid.

${ }^{49}$ Konings, "The Post-Colonial State and Economic and Political Reforms in Cameroon," 248; and Takougang, "The Nature of Politics in Cameroon," 76.

${ }^{50}$ DeLancey, "The Construction of the Cameroon Political System," 17; and Minorities at Risk 2009.

${ }^{51}$ Gros, "The Hard Lessons of Cameroon," 122; Konings, "The Post-Colonial State and Economic and Political Reforms in Cameroon," 251; and Minorities at Risk 2009.

52 Gros, "The Hard Lessons of Cameroon," 117-120; and Takougang, "The Post-Ahidjo Era in Cameroon,” 296.

${ }^{53}$ Gros, "The Hard Lessons of Cameroon," 121.

${ }^{54}$ Opalo, “African Elections: Two Divergent Trends,” 88.

${ }^{55}$ Freedom House, “Cameroon.”

${ }^{56}$ Opalo, “African Elections: Two Divergent Trends," 80. 